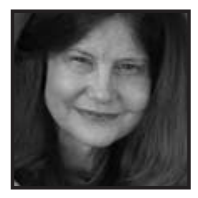

\title{
Commentary:
}

\section{Early Literacy Development and Implications for Practice}

\author{
Anne Haas Dyson, University of Illinois at Urbana-Champaign
}

\section{ABSTRACT}

In this interview with Anne Haas Dyson she discusses literacy, examining the connection between language, culture, and the positive impact of play. Anne speaks about the importance of incorporating literacy into the everyday life of children, and encouraging creativity and peer collaboration in the home as well as in classrooms. She stresses that children's literacy skills must be assessed within context, taking into consideration the child's perspective and the resources available. She emphasizes the individuality of every child's learning experience and the right for children to progress at their own speed.

How would you define literacy for 2009?

always define literacy as some kind of deliberate use of the symbol system to participate in some kind of sociocultural practice. When you watch little kids, the writing is usually all wound up with the talking and, if it's allowed in the classroom, the drawing and the playing. So I have a pretty broad definition anyway. But I think the ways in which these other symbol systems are now figuring... I mean when I started, in the late seventies trying to find disciplined ways of observing kids, I'd see this multi-modality, but I had the idea that eventually the kids would learn to accomplish in written language what they were accomplishing in other symbol systems. With that understanding, of course, meanings are not directly transferable. They would, for example, do less drawing and more writing. 
So everything is much more multi-modal, and the emphasis I think now is on flexibility. But at the same time I don't think that we need to act like this is some dramatic new thing. Because when you watch little kids you see all these capacities. They are quite multi-modal, they're quite flexible. So I think we have to consider what the curricular path should be to outcomes.

You have spoken about the baby genius edutainment complex, and the Einstein-in-the-Crib notion. Say a little bit about these expressions.

Well I think that was from a fellow interested in these ways of exploiting infancy by having these tapes for little bitty children as though this would do something for them. The idea that playing a tape is going to do something for a little bitty child is just nonsense. It's just silliness, and it shows something about some kind of gullibility of the populace. Because children, as we know, learn through interaction, with other people and with their environment. In the district I've been in lately, there is no playtime, even in the kindergartens; there's just none, there is absolutely none. It's not mentioned in the curriculum, there's no allotment made for play at all. Of course, the children still play, but it's undercover, it's on the side, it's being naughty. But in general the increasing devaluing of the agency of children, of the importance of play, and even of the centrality of interactions to learning, is rather disheartening, not to mention just silly. It just struck me as silly, and if it weren't so pervasive it would be funny, but instead it's rather sad.

So then, what advice would you give to parents about early literacy learning?

Well, I would say that literacy is going to be a part of language-filled activities, and that probably any time in the daily life when literacy figures into for them, it could figure into their child. I just saw a nice example yesterday. I went to a shopping centre and there was this dad who was walking with this little kid. And as they were walking from the parking lot they were looking at all the signs in the stores and the dad was saying, "Now, we're going to go to Staples. Where do you think it says Staples?" And the kid was so engaged and having such a good time, and I thought, well now there's just a little mundane thing, but through interaction it's been opened up to include the child. And it's a moment of closeness between them, the dad and the child, and they're happy together, and it's showing literacy as part of everyday life.

Now, the classic thing everybody refers to is reading to children, and I think that is a wonderful activity. It's close, you get the particular kind of language that may be in the book, and an opportunity for interaction, but that's not the only way it needs 
to happen. So, I think about reading the newspaper, or checking the weather, making a grocery list. Any of the daily activities can become occasions for child participation in the doings of the family.

And then, more broadly, since school literacy often entails this extended use of language, storytelling is important. Not just reading stories, but telling stories of any kind, of whatever kind of storytelling goes on in the family, and involving the child in the storytelling. So there is this extended use of language. I would say that was important.

So what should early literacy teaching and learning look like in classrooms?

If I stick to written language itself, I would think not in terms of just one kind of central activity, but I think that there can be multiple ways in which written language can be woven into the texture of the day. I think that there can be times when kids get together, like in the morning, when kids tell the important things that are happening, and the teacher takes dictation. That can happen in lots of different ways. The kids can jointly write their remembrances of yesterday and their anticipations for today, or one child can tell something important that happened, and gradually they all take their turn, and there is this collective writing of personal and classroom history. So I think that that's a good activity. I think that things like having access to materials so that we could take orders in our restaurants and we could build signs for our roads, and we could make labels for our apartment buildings, so that literacy is brought into constructive and dramatic play that I hope would be going on in an early childhood classroom. Then I think writing and reading work together. I like a daily time when the kids can have their journals or their writing books in which they draw and write, but I'm not big on mandating what that should be. That can be an open-ended time. We can write together in particular kinds of genres when we do activities throughout the day. And we can take our cue from the child. There is plenty of space for lots of teacher actions. We can take dictation sometimes, old language experience stories, we can have children write themselves and they can draw and tell us what they're doing, we can help them label it depending on what the children know, and how we can build on what they know.

How do you help pre-service or graduate students who are teachers understand and develop the competencies needed for teaching literacy in these more ideal types of early literacy classrooms? 
I work on having them understand what it is they're trying to teach, first of all. If you think that what you're teaching is just the $A B C^{\prime}$ 's and the sounds of the letters and the rest of the listed skills, then your way of looking at children is going to be different than if you think that what you are doing is trying to have the kids participate in varied kinds of literacy practices in which they will organize their skills, and, through interaction with other people, and the material resources available, in the activity, they will participate more skilfully over time. It matters how they think about it. So we have to work on what's behind the eyeballs, and being able to look positively at the resources of children. So, if teachers are not questioning the judgments that they're making about kids based on what comes out of their mouths, if they are thinking "deficit-y" instead of this is what, in my case, this is what America sounds like, it's going to be a problem. And related to that, is being able to look positively at the resources of children. Because childhood is all wound up now with popular culture, and the kids are coming with the TV and the music and the films and many children are coming with the video games and computer experiences.

\section{So then, what should literacy assessment look like and why?}

Well, first we have to figure out what it is that we want the kids to be able to do. So we have some ideas of the kinds of practices or events in which we want to see kids participate. But in general we know that you can't look at one kind of practice, one kind of event, and make any statement about the repertoire of children, right? So, again, I think we have to think about those components of any kind of language or literacy activity, "Who are they?" Who are they using language with and who are they using language for? So what access to help is there? That's a sort of Vygotskian idea. It's just not what you can do when you're sitting there all by yourself, but when you're engaging with other people. What's the range of purposes for which a child is comfortable or gaining access to using written language? Maybe they won't read this kind of book but they'll read that kind of book. Maybe if you ask them to do such-andsuch you'll get nothing but if they're writing the letter to somebody you'll get something. What's the channel of communication? What language do they have to use? How welcoming is the school of the language of the child? Is there any access, can they accompany their written language with any other symbolic medium? I think you can't really assess the language and literacy of a child without at the same time assessing the nature of the activity through which you're going to make judgments about the child. So you always see the child in context. And you vary that kind of context so that you can get a sense of the repertoire of children. So certainly when I look at kids, I, in writing in particular, I certainly care about the basic things like what they know about the symbol system and how it works. But I also know that how they're 
going to use that symbol system is going to vary depending on the nature of the activity. If they're all by themselves, they might put down anything, but if they are sitting with other kids, who are trying to figure out how to spell such and such...

But I guess the basic idea is if you want to know what a kid knows, you'll never look just in one way, you can't separate the child from the context. So you'll have to vary the context in order to get a full picture of the possibilities of the child.

In the best of all worlds, describe a future scenario for early literacy.

In the best of all worlds there would be a sense of time as being experienced differently by children. That they would have time to learn. So I would like to see these year-by-year, mandated, rather dated standards go. I think we have to have common visions of what we want for our children, but we have to give them time. We have to give them time to figure out the way that written language figures into their life. They have to have time to learn. They simply have to have time, and that is going to vary child by child by child. So, in an ideal world, the kids would have time and they would have space, so there would be diversity of activities and they would have some choice. I would like to see time and space being negotiable for kids, for young kids. And I see the other thing I said was that I would like to see the kids having some agency, some choice and a rich variety of possible activities in which to participate and I would like them to have observant teachers who knew how to pay attention to what the kids were doing and to take advantage of teachable moments and help them along the way. I would like to see a new respect for child culture and childhood so that time to learn in childish ways would be okay for children. They could have playful approaches to literacy, and they could have collective approaches.

\section{Do you have any last comments that you would like to make?}

Let's see. I think sometimes, it's a little discouraging. I think right now, sometimes I feel really, really hopeful and excited, and sometimes I feel really discouraged. And I think I'm in kind of a discouraged moment. I think the discouraged moment happens for two reasons. One thing I think people were working on long, long ago, like in the late sixties when I was being trained as a teacher, people were really into the diversities of Englishes, and in the seventies, everyone was taking courses on linguistic diversity. But now, I have students in the doctoral program who don't know anything at all about language, that languages are, by definition, articulated in variance. And that children, when they open their mouths, have echoes of their sociocultural histories and identities, and this should be treated with care. 




Anne Haas Dyson is a former teacher of young children and, currently, a professor of education at the University of Illinois at Urbana-Champaign. Previously she was on the faculty of the University of Georgia, Michigan State University, and the University of California, Berkeley, where she was a recipient of the campus Distinguished Teaching Award. She studies the childhood cultures and literacy learning of young schoolchildren. Among her publications are Social Worlds of Children Learning to Write in an Urban Primary School, which was awarded the National Council of Teachers of English David Russell Award for Distinguished Research, Writing Superheroes, and The Brothers and Sisters Learn to Write:Popular Literacies in Childhood and School Cultures. She recently coauthored two books with Celia Genishi, On the Case, on interpretive case study methods, and Children, Language, and Literacy: Diverse Learners in Diverse Times. 